\title{
Ablation of AMP-activated protein kinase $\alpha 1$ and $\alpha 2$ from mouse pancreatic beta cells and RIP2.Cre neurons suppresses insulin release in vivo
}

\author{
G. Sun • A. I. Tarasov • J. McGinty • A. McDonald • G. da Silva Xavier • T. Gorman • \\ A. Marley • P. M. French • H. Parker • F. Gribble • F. Reimann • O. Prendiville • \\ R. Carzaniga • B. Viollet • I. Leclerc • G. A. Rutter
}

Received: 19 November 2009 / Accepted: 1 February 2010 /Published online: 11 March 2010

(C) Springer-Verlag 2010

\begin{abstract}
Aims/hypothesis AMP-activated protein kinase (AMPK) is an evolutionarily conserved enzyme and a target of glucose-lowering agents, including metformin. However, the precise role or roles of the enzyme in controlling insulin secretion remain uncertain.

Methods The catalytic $\alpha 1$ and $\alpha 2$ subunits of AMPK were ablated selectively in mouse pancreatic beta cells and hypothalamic neurons by breeding Ampka1 [also known as Prkaal]-knockout mice, bearing floxed Ampk 2 [also known as Prkaa2] alleles (Ampk $\alpha 1^{-/-}, \alpha 2^{f l f l}$,), with mice expressing Cre recombinase under the rat insulin promoter (RIP2). RIP2 was used to express constitutively activated AMPK selectively in beta cells in transgenic mice. Food intake, body weight and urinary catecholamines were
\end{abstract}

Electronic supplementary material The online version of this article (doi:10.1007/s00125-010-1692-1) contains supplementary material,

which is available to authorised users.

G. Sun · A. I. Tarasov · A. McDonald · G. da Silva Xavier •

I. Leclerc $(\bowtie) \cdot$ G. A. Rutter $(\bowtie)$

Section of Cell Biology, Division of Diabetes,

Endocrinology and Metabolism, Department of Medicine,

Faculty of Medicine, Imperial College London,

Sir Alexander Fleming Building, Exhibition Road,

South Kensington,

London SW7 2AZ, UK

e-mail: i.leclerc@imperial.ac.uk

e-mail: g.rutter@imperial.ac.uk

J. McGinty $\cdot$ P. M. French

Photonics Group, Department of Physics,

Imperial College London,

London, UK

T. Gorman · A. Marley

AstraZeneca,

Alderley Edge, UK measured using metabolic cages. Glucose and insulin tolerance were determined after intraperitoneal injection. Beta cell mass and morphology were analysed by optical projection tomography and confocal immunofluorescence microscopy, respectively. Granule docking, insulin secretion, membrane potential and intracellular free $\mathrm{Ca}^{2+}$ were measured with standard techniques.

Results Trigenic Ampk $\alpha 1^{-/-}, \alpha 2^{f l f l}$ expressing Cre recombinase and lacking both AMPK $\alpha$ subunits in the beta cell, displayed normal body weight and increased insulin sensitivity, but were profoundly insulin-deficient. Secreted catecholamine levels were unchanged. Total beta cell mass was unaltered, while mean islet and beta cell volume were reduced. AMPK-deficient beta cells displayed normal glucose-induced changes in membrane potential and intracel-

H. Parker · F. Gribble $\cdot$ F. Reimann

Cambridge Institute of Medical Research,

Cambridge, UK

O. Prendiville

Charing Cross Hospital, Imperial College London,

London, UK

R. Carzaniga

Electron Microscopy Centre, Imperial College London,

London, UK

B. Viollet

Institut Cochin, Université Paris Descartes, CNRS (UMR 8104),

Paris, France

B. Viollet

Inserm,

U1067 Paris, France 
lular free $\mathrm{Ca}^{2+}$, while granule docking and insulin secretion were enhanced. Conversely, $\beta$ AMPK transgenic mice were glucose-intolerant and displayed defective insulin secretion. Conclusions/interpretation Inhibition of AMPK activity within the beta cell is necessary, but not sufficient for stimulation of insulin secretion by glucose to occur. AMPK activation in extrapancreatic RIP2.Cre-expressing cells might also influence insulin secretion in vivo.

Keywords AMPK · Beta cell · Insulin secretion · Islet . Knockout $\cdot$ RIP.Cre

\begin{tabular}{|c|c|}
\hline \multicolumn{2}{|l|}{ Abbreviations } \\
\hline AICAR & $\begin{array}{l}\text { 5-Aminoimidazole-4-carboxamide } \\
\text { ribonucleotide }\end{array}$ \\
\hline AMPK & AMP-activated protein kinase \\
\hline AMPK.CA & $\mathrm{AMPK} \alpha 1^{312} \cdot \mathrm{T} 172 \mathrm{D}$ \\
\hline$\beta$ AMPKdKO & $\begin{array}{l}\text { Ampk } \alpha 1^{-/-}, \alpha 2^{f l f l} \text { mice expressing Cre } \\
\text { recombinase }\left(A m p k \alpha 1^{-/-}, \alpha 2^{f l f l}, C r e^{+}\right)\end{array}$ \\
\hline AMPK.DN & AMPK $\alpha 2 . D 157 \mathrm{~A}$ \\
\hline $\mathrm{K}_{\text {ATP }}$ & ATP-sensitive $\mathrm{K}^{+}$ \\
\hline LKB1 & Liver kinase B1 \\
\hline mTOR & Mechanistic target of rapamycin \\
\hline RIP & Rat insulin promoter \\
\hline ZO-1 & Zona occludins-1 \\
\hline
\end{tabular}

\section{Introduction}

AMP-activated protein kinase (AMPK) is an evolutionarily conserved fuel-sensitive protein kinase implicated in the control of glucose homeostasis and playing roles in insulinsensitive tissues [1-3] and in the pancreatic beta cell [4-7]. While the stimulation of AMPK activity in muscle and liver is now seen as a likely mechanism through which glucoselowering agents, including metformin and thiazolidinediones, act to improve insulin sensitivity [8], the long-term effects of these agents on pancreatic beta cell survival and insulin release are less clear [7].

Mammalian AMPK is a trimeric protein comprising a catalytic $\alpha$-subunit, encoded by one of two separate genes (Ampkol [also known as Prkaal] and Ampko2 [also known as Prkaa2]), a scaffold $\beta$ - ( $\beta 1$ or $\beta 2)$ subunit and a regulatory $\gamma$-subunit $(\gamma 1, \gamma 2$ or $\gamma 3)[9,10]$. The existence of two separate AMPK $\alpha$ subunit genes has so far hindered investigations of the role AMPK activity plays in controlling glucose homeostasis in mammals, since the unconditional deletion of both isoforms leads to early embryonic lethality in mice [11]. By contrast, animals with global inactivation of the AMPK $\alpha 1$ isoform do not display significant metabolic abnormalities [11, 12]. Deletion of the Ampka2 gene leads to insulin resistance and glucose intolerance, in part due to increased parasympathetic tone [13]. Whereas insulin secretion was normal in islets isolated from whole-body Ampko 2 knockout mice, insulin release in vivo appeared to be diminished when measured at a single time point during oral glucose tolerance tests. However, no measurements were made during intraperitoneal glucose tolerance tests, where the complicating effects of potentially altered incretin release could be excluded. Importantly, since complexes containing the AMPK $\alpha 1$ isoform are substantially (>tenfold) more abundant in beta cell lines than AMPK $\alpha 2$ complexes [5], increases in expression of the former may also, in part, have compensated for the loss of AMPK $\alpha 2$.

The cell-permeant AMPK activator, 5-aminoimidazole4-carboxamide ribonucleotide (AICAR), diminishes glucose-stimulated insulin secretion from clonal beta cells and islets [4, 6], an effect mimicked by the biguanide metformin [14] or by the expression of a constitutively active form of AMPK [6]. Moreover, overexpression of constitutively active AMPK diminished the performance of islets transplanted into streptozotocin-induced diabetic mice [15]. These actions may be due in part to blockade of secretory granule transport to the cell surface [16] as a result of kinesin-1 light chain phosphorylation [17]. In addition, AMPK activation decreases beta cell viability $[18,19]$ possibly by phosphorylating the cell cycle regulator, p53 [20]. By contrast, inhibition of AMPK activity with dominant-negative forms of the enzyme tends to increase insulin secretion at low glucose concentrations [6] without affecting release at elevated glucose concentrations [21], a finding that is consistent with inactivation of the enzyme as a result of AMP depletion under these conditions.

AMPK is also thought to play an important role in the central control of feeding and glucose homeostasis. Thus, forced changes in AMPK in the ventromedial hypothalamus achieved by stereotactic injection of viral vectors led to marked changes in food intake and body weight [22] and in hypoglycaemia sensing [23, 24]. Moreover, the deletion of Ampko2 in neurons expressing pro-opiomelanocortin or agouti-related peptide leads respectively to increased or decreased food intake in mice [25]. Finally, manipulation of AMPK activity ex vivo was found to affect glucose-induced changes in the electrical activity of $\mathrm{Ca}^{2+}$ transients in isolated agouti-related peptide (glucose-inhibited), but not in pro-opiomelanocortin (glucose-responsive) neurons in culture [26, 27].

We have previously demonstrated distinct roles in the pancreatic beta cell for AMPK complexes containing differing catalytic subunits [5]. Thus, the $\alpha 2$ subunit, which displayed substantial nuclear localisation [4, 5], was implicated in control of gene expression, whereas $\alpha 1$ containing complexes, whose total activity exceeded that of $\alpha 2$-containing complexes by five to ten fold [5], were almost exclusively cytosolic. The role of the latter remains unclear, but may include regulation of plasma membrane 
ion channels, as proposed in oxygen-sensing cells in the carotid body [28].

To assess the role of AMPK in insulin-expressing cells, we generated trigenic mice that were globally inactivated for Ampka1 and had Ampka2 deleted selectively in pancreatic beta cells and in a small population of hypothalamic neurons, using the rat insulin promoter (RIP)2 [29] and transgenic mice expressing activated AMPK selectively in beta cells. Using these models we highlight multiple novel mechanisms through which AMPK controls insulin production and glucose homeostasis in mammals.

\section{Methods}

Generation of mutant mice lacking Ampk $\alpha 1$ globally and selectively lacking $A m p k \alpha 2$ in pancreatic beta cells and RIP2.Cre neurons

$A m p k \alpha 1^{+/-}, \alpha 2^{f l f f l}(f l / f l)$ mice were first crossed with wildtype C57BL/6 mice to generate double heterozygous $A m p k \alpha 1^{+/-}, \alpha 2^{f l /+}$ mice. Offspring were then crossed with heterozygous RIP2.Cre ${ }^{+}$transgenic mice (expressing Cre recombinase under the RIP2; Jackson Laboratory, Bar Harbor, ME, USA). The resulting triple heterozygous AMPK $\alpha 1^{+/-}, \alpha 2^{f l /+}, C r e^{+}$mice were interbred with their siblings. Since RIP2.Cre transgenic mice have been suggested to show glucose intolerance and impaired insulin secretion $[30,31], \mathrm{Cre}^{+}$mice were always used as a negative control. Due to the low probability $(1: 64)$ of obtaining double knockout mice through heterozygote crossing, two different breeding strategies were used to obtain double AMPK knockout mice and their littermate controls. First, to generate Ampk 1 l-knockout mice, bearing floxed $A m p k \alpha 2$ alleles $\left(A m p k \alpha 1^{-/}, \alpha 2^{f l f l}\right)$ and expressing Cre recombinase ( $\beta$ AMPKdKO) and their heterozygous $A m p k \alpha 1^{+/-}, \alpha 2^{f l / t}, C r e^{+}$mice controls, Ampk $\alpha 1^{-/-}, \alpha 2^{f l /+}$, $\mathrm{Cre}^{-}$and $\mathrm{Ampk \alpha 1^{+/- }}, \alpha 2^{f l / f l}, \mathrm{Cre}^{+}$mice were crossed. Second, to produce heterozygous $\mathrm{Ampk \alpha 1^{+/- }}, \alpha 2^{f l /+}, \mathrm{Cre}^{+}$and their wild-type $A m p k \alpha 1^{+/+}, \alpha 2^{+/+}, \mathrm{Cre}^{+}$littermate controls, $A m p k \alpha 1^{+/-}, \alpha 2^{f l /+}, \mathrm{Cre}^{+}$and wild-type mice were crossed. All mice were kept on a C57BL/6 background and offspring genotypes were obtained in the expected Mendelian ratios.

Generation of mutant mice selectively overexpressing AMPK.CA or -DN in pancreatic beta cells and RIP.Cre neurons

An expression vector containing the RIP2 promoter fragment (600 bp), c-myc-tagged rat AMPK $\alpha 1^{312}$.T172D (CA) or AMPK $\alpha 2$.D157A (DN) cDNA, and an SV40 poly
(A) cassette was excised with BssHII and microinjected into the male pronucleus of fertilised C57BL/6 oocytes. The injected zygotes were re-implanted into pseudo-pregnant female C57BL/6 mice (GenOway, Lyon Cedex, France). We obtained three AMPK.CA (named C1, C2 and C10) and two AMPK.DN (D1 and D2) founder mice that stably transferred the corresponding transgenes to their offspring. Founder mice were crossed with wild-type C57BL/6 mice to achieve F1 generation. Distributions of genotypes in the offspring followed a Mendelian pattern. All AMPK transgenic mice were kept heterozygous. F3 and later generations, and their littermate wild-type controls were used for experiments. All lines were maintained on a pure C57BL/6 background.

Mouse maintenance and diet

Mice were housed two to five animals per cage in a pathogen-free facility with $12 \mathrm{~h}$ light/dark cycle and had free access to standard mouse chow diet or a high-fat diet $(60 \%[\mathrm{wt} / \mathrm{wt}]$ fat content; Research Diet, New Brunswick, NJ, USA). As indicated, 6-week-old mice were transferred to a high-fat diet for a maximum of 18 weeks. All in vivo procedures described here were performed at the Imperial College Central Biomedical Service and approved by the UK Home Office Animals Scientific Procedures Act, 1986.

Body weight and food intake

Fed mouse weights were monitored weekly after 6 weeks of age. Food intake was measured daily for three consecutive days using a metabolic cage.

In vivo physiological studies

Intraperitoneal glucose tolerance test Mice fasted for $15 \mathrm{~h}$ (water allowed) were intraperitoneally injected with $1 \mathrm{~g}$ glucose $/ \mathrm{kg}$ mouse weight. Blood from the tail vein was obtained at $0,15,30,60,90$ and 120 min after injection. Blood glucose levels were measured with an automatic glucometer (Accuchek; Roche, Burgess Hill, UK). To study the effect of $\alpha$-adrenergic antagonist on glucose tolerance, mice were intraperitoneally injected with $10 \mathrm{mg} / \mathrm{kg}$ mouse weight phentolamine $30 \mathrm{~min}$ before glucose challenge.

Plasma insulin measurement Mice fasted for $15 \mathrm{~h}$ were intraperitoneally injected with $3 \mathrm{~g}$ glucose $/ \mathrm{kg}$ mouse weight. Blood from mice tail veins was collected into a heparin coated tube (Sarstedt, Beaumont Leys, UK) at 0, 15 and 30 min after injection. Plasma was separated by centrifuging the blood at 2,000 $\mathrm{g}$ for $5 \mathrm{~min}$. Plasma insulin levels were measured using an ultrasensitive mouse insulin ELISA kit (Mercodia, Uppsala, Sweden). Normal fed plasma insulin levels were 


\section{a}

Ampka1 $+1+++1-+1-+1+-1++/+++1$

Ampka2 f/f $f / f f /+f /+f / f / f$ f/f

$\mathrm{Cre}^{+} \quad-+++++$

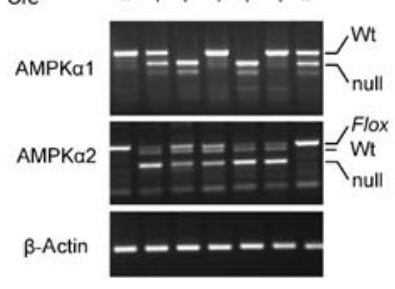

e

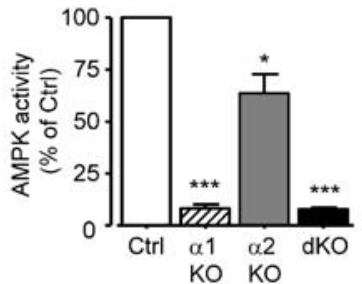

b

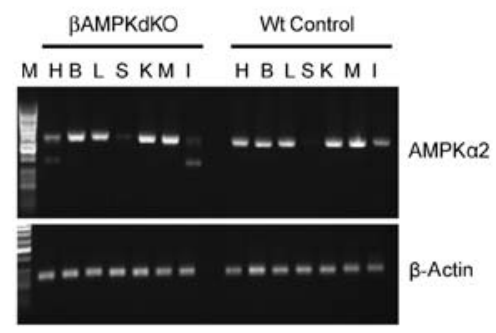

f c

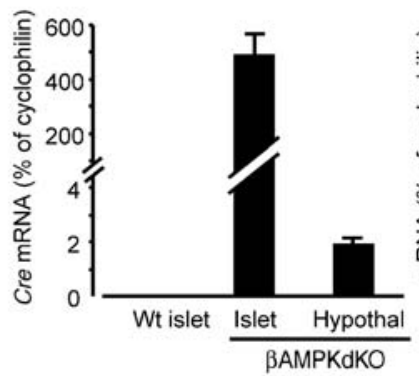

g d

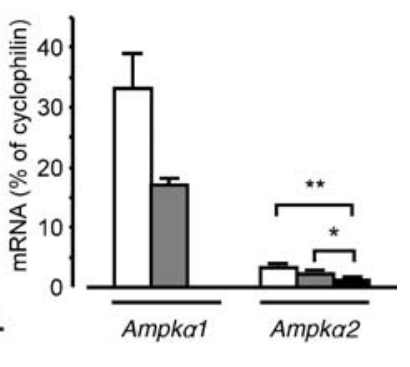

Fig. 1 Generation of $\beta$ AMPKdKO mice. a RT-PCR analysis of the deletion of AMPK $\alpha 1$ and $-\alpha 2$ isoforms in islets from mice with the indicated genotypes $(n=3-4)$ and (b) of $A m p k \alpha 2$ gene expression in hypothalamus $(\mathrm{H})$, brain cortex $(\mathrm{B})$, liver $(\mathrm{L})$, spleen $(\mathrm{S})$, kidney $(\mathrm{K})$, muscle (M) and islet (I). cDNA generated by reverse transcription of extracted mRNA was analysed using primers targeting aa97-157 of AMPK $\alpha 1$ and aa189-260 of AMPK $\alpha 2$. For AMPK $\alpha 1$, the product sizes were 588 and 408 bp for wild-type (Wt) and knockout alleles (null) respectively. The corresponding values for AMPK $\alpha 2$ were 588 and 375 bp. c Cre mRNA levels in isolated islets and hypothalamic extracts and (d) analysis of deletion of Ampko1 and Ampko2 in pancreatic islets. mRNA levels were quantified by qRT-PCR (see ESM 1). The indicated genotypes refer to the AMPK $\alpha$ isoform only. White bars, Wt; grey bars, heterozygous; black bars, ßAMPKdKO. e Total AMPK activities in pancreatic islets from control (Ctrl; Ampkol $1^{+/-}$, $\left.\alpha 2^{f l f l}, C r e^{-}\right)$, AMPK $\alpha 1$ whole-body knockout ( $\alpha 1 \mathrm{KO}$; Ampk $\alpha 1^{-/}$,' $\left.\alpha 2^{f l f l}, C r e^{-}\right), \beta$ AMPK $\alpha 2 \mathrm{KO}\left(\alpha 2 \mathrm{KO}\right.$; A $\left.A m p k \alpha 1^{+/}, \alpha 2^{f l f l}, \mathrm{Cre}^{+}\right)$or $\beta$ AMPKdKO (dKO;Ampk $\left.\alpha 1^{-1-}, \alpha 2^{f l l f l}, C r e^{+}\right)$mice. f Body weight changes in $\beta$ AMPKdKO (triangles) or control (circles; Ampkol $1^{+/-}$, $\left.\alpha 2^{f l /+}, \mathrm{Cre}^{+}\right)$mice. g Food intake in fed mice (see Methods). Het, heterozygous. Data are expressed as means \pm SEM; $n=3-5$ (c, e) or $n=$ 7-9 (f, $\mathbf{g}) ;{ }^{*} p<0.05,{ }^{* *} p<0.01,{ }^{* * *} p<0.001$

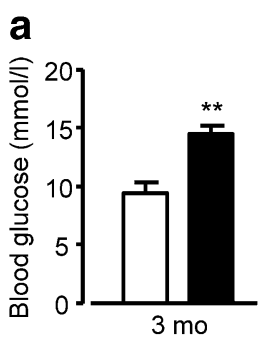

e

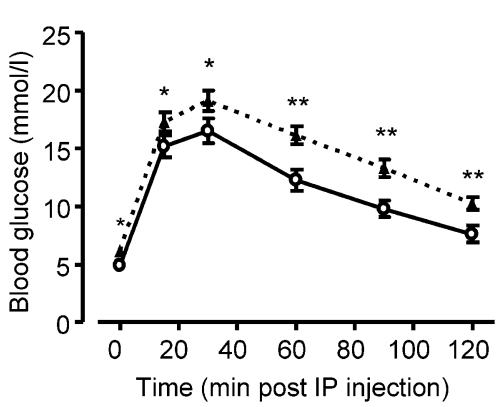

b

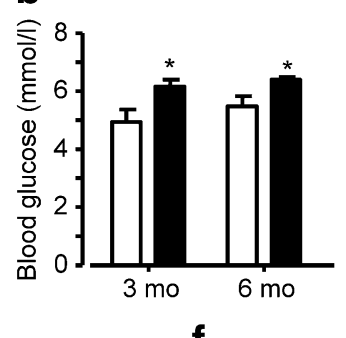

f

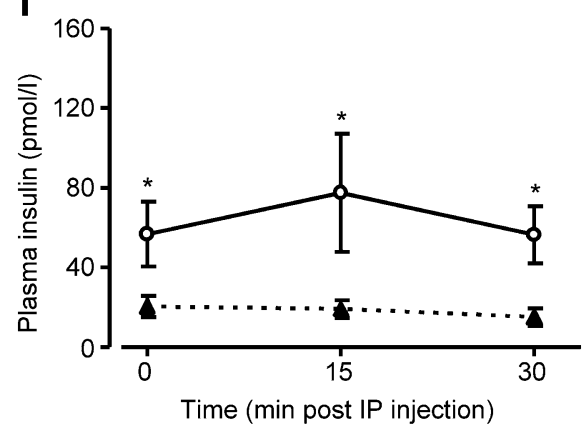

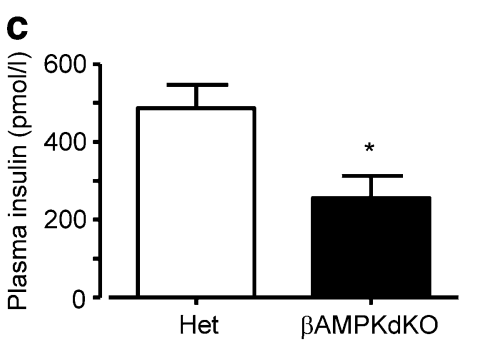
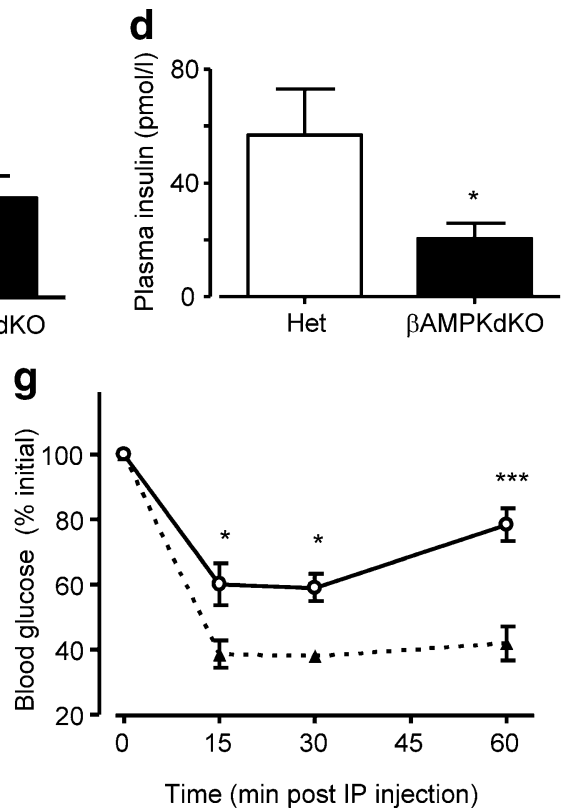

Fig. 2 Glucose homeostasis in $\beta$ AMPKdKO mice. Blood glucose (a, b) and plasma insulin (c, d) levels in 3- (a) or 3- and 6-month-old mice (b), or in 3-month old mice $(\mathbf{c}, \mathbf{d})$. For $\mathbf{b}, \mathbf{c}$, mice were fasted for $15 \mathrm{~h}$. White bars, heterozygous (Het); black bars, $\beta$ AMPKdKO. e Glucose tolerance and (f) plasma insulin response, after intraperitoneal (IP) glucose injection, and (g) whole-body insulin sensitivity after IP insulin injection. Triangles, $\beta$ AMPKdKO; circles, Het. Data are expressed as means \pm SEM; $n=7-9 ;{ }^{*} p<0.05,{ }^{* *} p<0.01,{ }^{* * *} p<0.001$ 
measured from blood collected from tail veins of 12-week-old mice between 10:00 and 11:00 hours.

Insulin tolerance test Bovine insulin $(0.75 \mathrm{U} / \mathrm{kg}$; Sigma, Dorset, UK) was intraperitoneally injected into fed mice between 13:00 and 14:00 hours. Blood glucose levels were measured at $0,15,30$ and 60 min after injection.

Urine collection and catecholamine measurement

Daily urine collection from each mouse for a period of 3 days was performed using metabolic cages. Catecholamine levels in urine were determined by reverse-phase HPLC.

Other methods

Details of islet isolation and insulin secretion, electron microscopy, electrophysiology, optical projection tomography, $\mathrm{Ca}^{2+}$ imaging, RNA extraction and RT-PCR, AMPK assay, antibodies and immunohistochemistry are provided in Electronic supplementary material (ESM 1).

Statistical analysis

Data are expressed as means \pm SEM. Significance was tested by two samples unpaired or paired Student's $t$ test using Excel, or by ANOVA using Graphpad 4.0. A value of $p<0.05$ was considered significant.

\section{Results}

$\beta$ AMPKdKO mice have normal body weight

but are hyperglycaemic

mRNAs encoding Ampk 1 and $-\alpha 2$ subunits were present in highly purified $[32,33]$ wild-type mouse beta cells (ESM Fig. 1). Ampka1 mRNA was $\sim 15$-fold more abundant than that encoding the $\alpha 2$ subunit, in line with previous AMPK activity measurements in clonal beta cells [5] and with the distinct roles of each isoform in these cells [5]. Since mice deleted globally for either subunit display essentially normal insulin release in vitro [13], we generated trigenic mice inactivated for AMPK $\alpha 1$ and $\alpha 2$ subunits selectively in beta cells and in a small population of hypothalamic neurons. Mice globally inactivated for Ampk $\alpha 1$ [11] were first crossed with animals bearing floxed $A m p k \alpha 2$ gene alleles (Fig. 1a). Crossing with RIP2.Cre mice [29] led to a selective loss of the catalytic domain of the Ampko2 subunit (aa189260) from islets and hypothalamus (Fig. 1a, b). Consistent with the abundant expression in islets of the Cre transgene (Fig. 1c) and selective deletion of the two catalytic subunits from beta cells [34], the crossing of Ampka2 floxed and RIP2.Cre mice resulted in a decrease in islet Ampko 2 mRNA of 60 to $70 \%$ (Fig. 1d). Assessed at low glucose concentrations to near-maximally stimulate the enzyme [14], total islet AMPK activity was decreased by $93 \%$ in $A m p k \alpha I^{-/-}$vs $A m p k \alpha 1^{+-}\left(\alpha 2^{\mathrm{fl} / \mathrm{fl}} \cdot \mathrm{Cre}^{-}\right.$in each case $)$mice and by $95 \%$ in $\beta$ AMPKdKO mice vs $A m p k \alpha I^{+/-}$(Fig. 1e).

Male $\beta$ AMPKdKO mice displayed entirely normal growth and normal food intake (Fig. 1f, g), while females had a small reduction in body weight up to 10 weeks of age (ESM Fig. 2a). Assessed at 3 (Fig. 2a, c) and 6 months (not shown) of age, $\beta$ AMPKdKO mice of either sex, but not mice deleted for either Ampko1 [12] or - $\alpha 2$ (ESM Fig. 3) alone, displayed markedly elevated plasma glucose and decreased plasma insulin levels (Fig. 2a-d, ESM Fig. 3). Correspondingly, double knockout mice displayed abnormal glucose tolerance and insulin release in vivo, despite increased insulin sensitivity (Fig. 2e-g, ESM Fig. 2c-e). No differences in glucose tolerance and insulin release or sensitivity were observed between $\mathrm{Ampk \alpha I^{+/+ }}, \alpha 2^{+/+}, \mathrm{Cre}^{+}$ and $A m p k \alpha 1^{+/-}, \alpha 2^{f l /+}, C r e^{+}$control mice (not shown).

Since mice with global homozygous deletion of Ampk $\alpha 2$ display abnormal insulin secretion in vivo and elevated catecholamine levels [13], we determined whether the latter variable may contribute to abnormal insulin secretion in
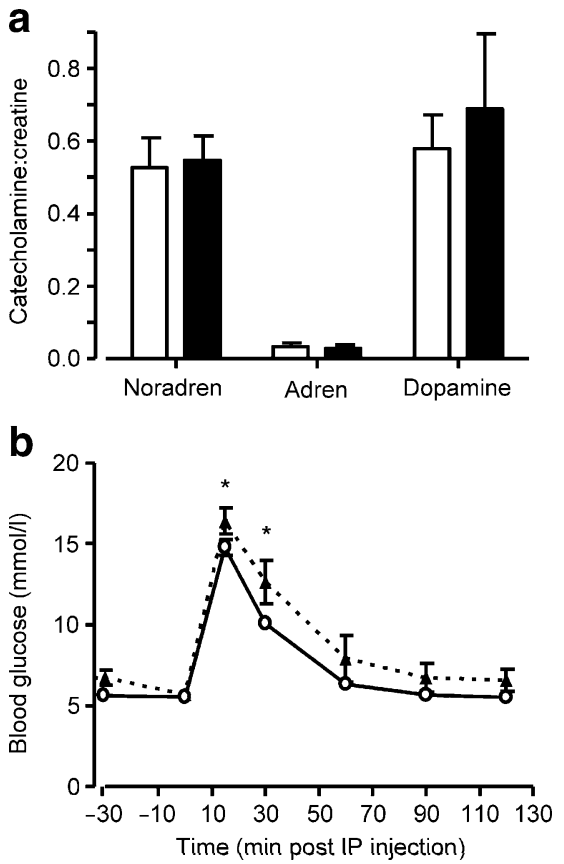

Fig. 3 Role of catecholamines in the control of insulin secretion in $\beta A M P K d K O$ mice. a Urinary noradrenaline (Noradren, norepinephrine), adrenaline (Adren, epinephrine) and dopamine levels. Black bars, $\beta$ AMPKdKO; white bars, heterozygous. b Glucose tolerance of $\beta$ AMPKdKO (triangles) or heterozygous control (white circles) mice $30 \mathrm{~min}$. after IP phentolamine injection. Male mice aged 12-14 weeks were used. Data are expressed as means \pm SEM; $n=6-8 ; * p<0.05$ 
$\beta$ AMPKdKO mice. We detected no alterations in the levels of urinary catecholamines (Fig. 3a), indicating that the above was not the case. Moreover, abnormal glucose tolerance was still observed, albeit diminished in extent, in the presence of the $\alpha$-adrenoreceptor blocker, phentolamine (Fig. 3b) [35].

$\beta$ AMPKdKO mice have normal beta cell mass but smaller beta cells and islets

Changes in relative beta cell mass, which might have explained the marked decrease in insulin release in $\beta A M P K d K O$ animals, were not observed as assessed by optical projection tomography of whole pancreases [36] (Fig. 4a-d; ESM video clips 1 and 2) or through analysis of pancreatic slices (ESM Fig. 4). However, the distribution of islet sizes between heterozygous and $\beta \mathrm{AMPKdKO}$ animals, as assessed by optical projection tomography, revealed a significant $\sim 40 \%$ decrease in the average volume of individual islets (Fig. 4b, c, e).

By contrast, no differences were apparent in the ratio of alpha to beta cells within individual islets or in the relative disposition of the two cell types (Fig. 5a). Similarly, despite proposed roles for AMPK and the upstream kinase liver kinase B1 (LKB1) in the control of beta cell polarity [37-39] (G. Sun, A.I. Tarasov, J. McGinty, P.M. French, A. McDonald, I. Leclerc and G. Rutter, unpublished results), we observed no abnormalities in the formation of adherens (anti-E-cadherin antibodies; Fig. 5b) or tight (anti-zona occludins-1 [ZO-1] antibody) junctions (Fig. 5c), and microfilament and microtubule structure were unchanged in islets from $\beta \mathrm{AMPKdKO}$ mice (not shown).

AMPK is a known regulator of the mechanistic target of rapamycin (mTOR) complex, acting to phosphorylate the mTORC1 components Raptor and the upstream regulator tuberous sclerosis complex-2 [40]. Since mTOR is involved in the regulation of cell size [41], we assessed the size of individual beta cells, using anti-E-cadherin (Fig. 5d, e) or anti-GLUT2 (not shown) antibodies to label the plasma membrane. This revealed an $\sim 18 \%$ decrease in the average area of beta cells, corresponding to a decrease in volume of $\sim 36 \%$, closely in line with the reduction in average islet size. However, no changes in the phosphorylation state of the downstream targets of mTOR, ribosomal S6 subunits, were detected (not shown), arguing against changes in the activity of the latter pathway being responsible for the decrease in beta cell volume. Unexpectedly, beta cell a
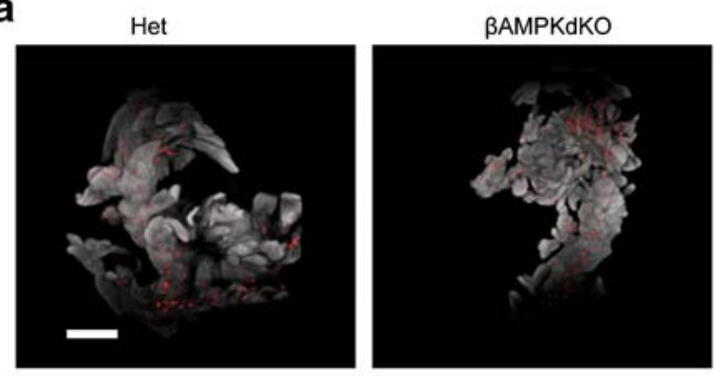

b

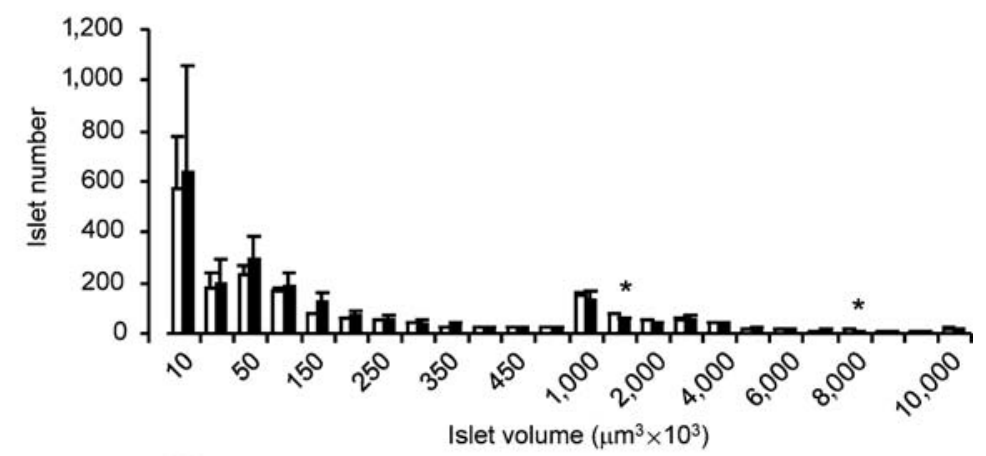

C

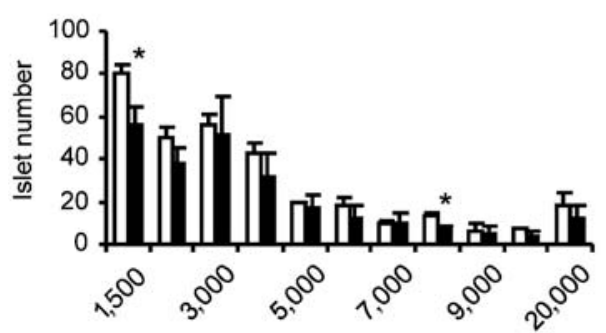

d

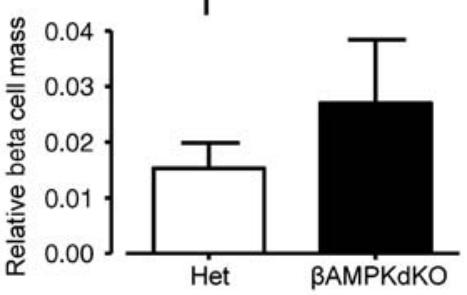

e

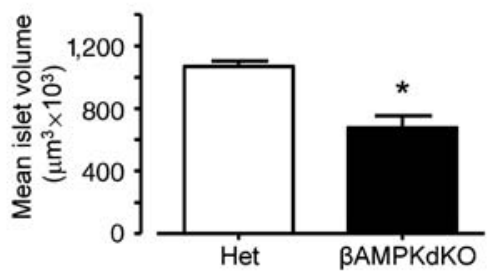

Islet volume $\left(\mu \mathrm{m}^{3} \times 10^{3}\right)$

Fig. 4 ßAMPKdKO mice have normal beta cell mass but small islets and beta cells. a Representative optical projection tomographic projections of whole fixed and permeabilised pancreases. Optical projection tomography was performed as described in ESM. Red, insulin-positive structures (beta cells within islets). The overall shape of the whole pancreas was visualised as autofluorescence and is apparent as white/grey shading. The images shown correspond to three dimensional projections; see also ESM clips 1 and 2. Het, heterozygous. Scale bar, $500 \mu \mathrm{m}$. b Distribution of islet volumes with marked (dotted lines) section magnified (c). Black bars, $\beta \mathrm{AMPKdKO}$; white bars, heterozygous. d Relative beta cell mass and (e) mean islet volume. Data are from $n=3$ whole mouse pancreases per genotype and are expressed as means $\pm \mathrm{SEM} ; * p<0.05$ 


\section{a

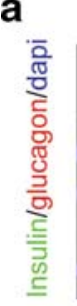

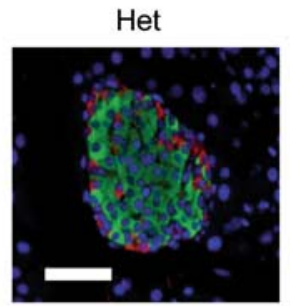

c
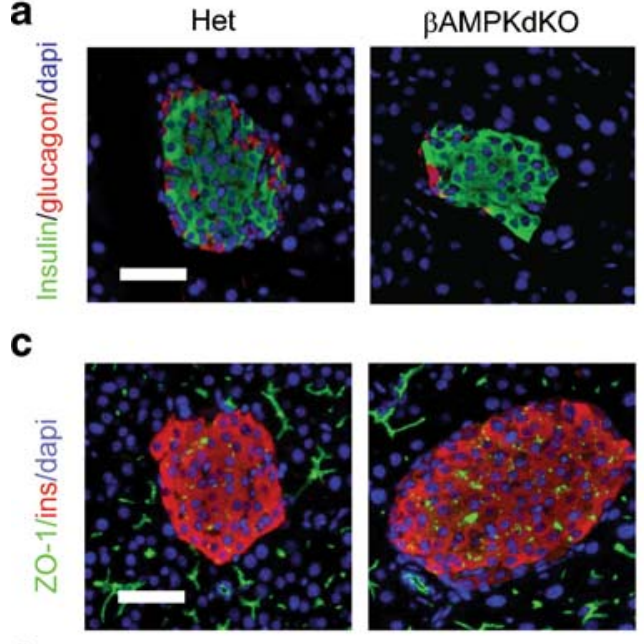

e
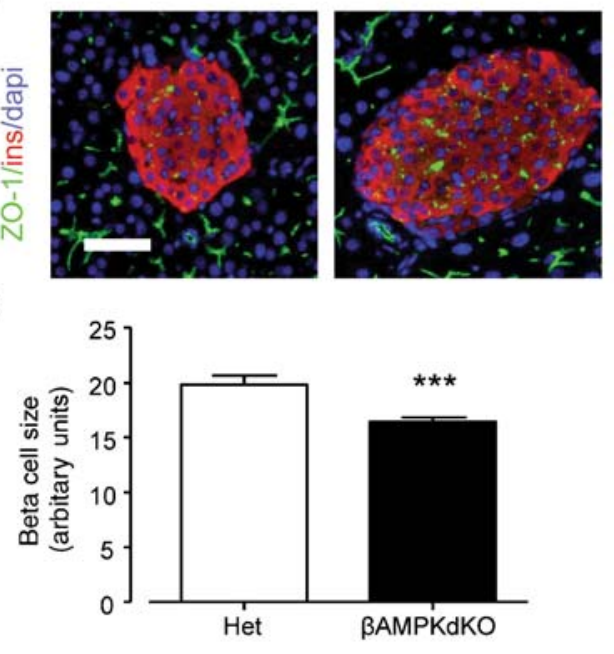

b
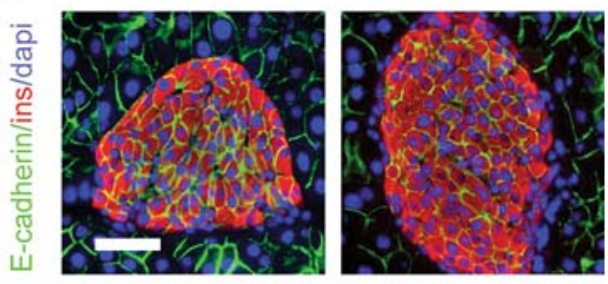

d
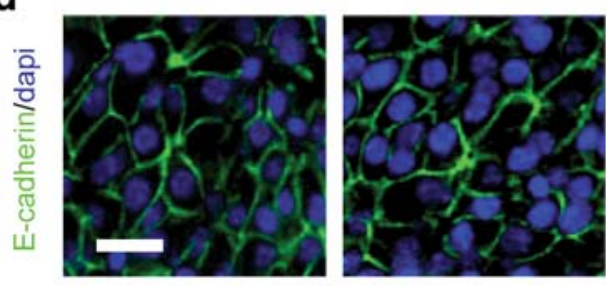

f
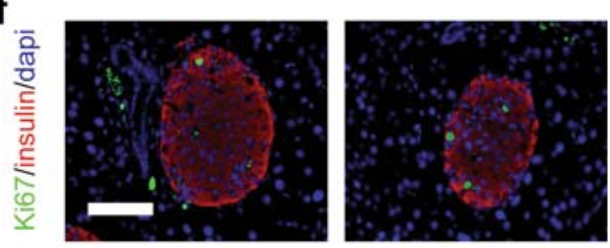

g

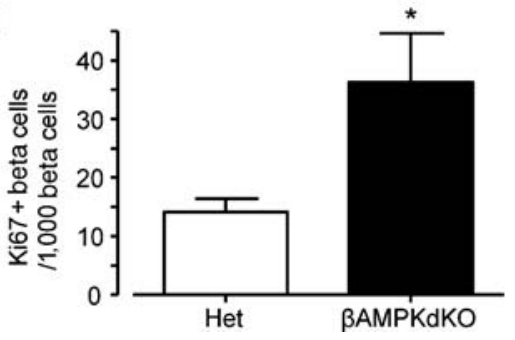

Fig. 5 Islet and beta cell morphology in $\beta A M P K d K O$ mice. Immunofluorescence staining of pancreatic sections with: (a) antiinsulin (1:200; red) and glucagon (1:100, green) antibodies; (b) the adherens junction marker E-cadherin (1:100; green); (c) tight junction marker ZO-1 (whole serum; green); and (d) representative E-cadherin staining of pancreatic sections and determination (e) of beta cell size (see ESM 1). Ten islets (containing $\geq 10$ cells) from $n=3$ mice of each genotype were analysed. f Staining for proliferation marker Ki67 and quantification (g), based on $8-10$ islets per pancreas, $n=3$ per genotype. Scale bars: $75 \mu \mathrm{m}(\mathbf{a}-\mathbf{c}, \mathbf{f}), 12 \mu \mathrm{m}(\mathbf{d})$. Data are expressed as means $\pm \mathrm{SEM} ;{ }^{*} p<0.05, * * * p<0.001$

cells, we next analysed insulin release from isolated islets and glucose-sensing by dissociated beta cells. In contrast to what was observed in vivo, islets from $\beta$ AMPKdKO mice displayed significantly elevated rates of glucose-stimulated insulin release compared with control (heterozygote) islets (Fig. 6a), arguing for a restraining effect of AMPK on hormone release. Unexpectedly, the previously described inhibitory effects of AMPK activation with the AMPK activator and AMP analogue AICAR [4, 6] were still preserved in $\beta A M P K d K O$ mouse islets, indicating that the effects of this activator were largely independent of AMPK.

To determine whether beta cells from $\beta$ AMPKdKO mouse islets show altered glucose sensing, as observed after LKB1 deletion (G. Sun, A. Tarasov, J. McGinty, P.M. French, A. 
McDonald, I. Leclerc and G. Rutter, unpublished results), we used electrophysiological approaches. While glucose-induced changes in the conductance of ATP-sensitive $\mathrm{K}^{+}$channels revealed lower conductance of these channels at low (3 $\mathrm{mmol} / \mathrm{l})$ but not elevated $(16.7 \mathrm{mmol} /)$ glucose in $\beta$ AMPKdKO beta cells compared with heterozygous controls, this did not translate into a difference in membrane potential changes (Fig. 6b, c). Likewise, no differences were apparent in the extent of glucose or depolarisation- (KCl-) induced increases in intracellular free $\mathrm{Ca}^{2+}$ ions in heterozygous compared with $\beta$ AMPKdKO beta cells (Fig. $6 \mathrm{~d}-\mathrm{g}$ ). Correspondingly, again in contrast to the impact of LKB1 deletion (G. Sun, A. Tarasov, J. McGinty, P.M. French, A. McDonald, I. Leclerc and G. Rutter, unpublished results), no differences were observed in the levels or plasma membrane association of the liver/beta cell glucose transporter Glut2 (Fig. 6h) [42]. By contrast, the number of morphologically docked granules was significantly increased in ßAMPKdKO beta cells (Fig. 6i, j).

We next determined whether AMPK present in beta cells and RIP2.Cre neurons contribute to the deleterious effects of a high-fat diet on insulin release and glucose homeostasis [43]. No differences in body weight gain were apparent between heterozygous and $\beta$ AMPKdKO mice maintained on high-fat diet (Fig. 7a). However, after 6 weeks on highfat diet, which is sufficient to cause profound abnormalities in glucose-induced insulin secretion in C57BL/6 mice [43], the differences in glycaemia observed between heterozygote and $\beta$ AMPKdKO mice observed on a normal diet

Fig. 6 Unaltered glucose-induced changes in membrane potential and intracellular free $\mathrm{Ca}^{2+}$ in $\beta$ AMPKdKO mouse beta cells, but enhanced granule docking and improved glucose-stimulated insulin secretion in isolated islets. a Glucose-stimulated insulin secretion of six sizematched islets from $\beta A M P K d K O$ and heterozygous mice (Het) statically incubated with $3 \mathrm{mmol} / \mathrm{l}$ (white bars) or $16.7 \mathrm{mmol} / \mathrm{l}$ (black bars) glucose or $400 \mu \mathrm{mol} / 1$ AICAR for $0.5 \mathrm{~h} ; n=3$ per genotype. b Representative traces of whole-cell $\mathrm{K}_{\mathrm{ATP}}$ channel conductance $\left(\mathrm{G}_{\text {KATP }}\right)$ and plasma membrane potential $(\mathrm{Vm})$ (c) from perforated patch clamp. Six to nine cells from three mice of each genotype were analysed. $\mathrm{nS} \mathrm{pF}$, nanosiemens picofarad; FCCP, carbonyl cyanide- $p$ trifluoromethoxyphenylhydrazone; Tolb, tolbutamide; triangles, Ampk $\alpha 1^{+/-}$; circles, Ampk $\alpha 1^{-/-}$; d Representative traces of free $\left[\mathrm{Ca}^{2+}\right]$ with fura-red in dissociated beta cells in heterozygous and (e) $\beta$ AMPKdKO mice, with quantification (f [AUC in arbitrary fluorescent units], g); 19-22 cells from two mice of each genotype were analysed. Glc, glucose; white bars, heterozygous; black bars, ßAMPKdKO. h Immunofluorescence staining of GLUT2 expression at the plasma membrane of pancreatic islet beta cells; 15 islets from two pairs of mice of each genotype were analysed. Scale bar, $75 \mu \mathrm{m}$. Het, heterozygous. i Granule docking in control (Het) or $\beta$ AMPKdKO beta cells; 15 cells from four separate islets, two mice per genotype were analysed by transmission electron microscopy. The relative number of morphologically docked granules was calculated by dividing that of docked granules (those within $400 \mathrm{~nm}$ of the plasma membrane) by that of total cytosolic granule number and is quantified in bar graph $(\mathbf{j})$, see ESM 1. Scale bar, $2 \mu \mathrm{m}$. Data are expressed as means \pm SEM; $* * * p<0.001$

(Fig. 2a, b, e) were abolished (Fig. 7b). This change reflected a more dramatic increase in glucose levels in the heterozygous mice on high-fat diet than in those on normal chow (Figs $2 \mathrm{a}$ and $7 \mathrm{~b}$ ). Likewise, the difference in glucose tolerance observed between $\beta$ AMPKdKO and heterozygous mice on normal chow ( $\sim 5 \mathrm{mmol} / \mathrm{l}$ at $60 \mathrm{~min}$; Fig. 2e) was substantially reduced when the comparison between genotypes was performed in mice maintained on high-fat diet $(\sim 2 \mathrm{mmol} / 1$ at $60 \mathrm{~min}$; Fig. $7 \mathrm{c})$. By contrast, the enhanced insulin sensitivity of $\beta$ AMPKdKO mice $(\sim 20 \%$ of the initial glucose level $30 \mathrm{~min}$. post insulin injection; Fig. 2 g) was maintained or enhanced on high-fat diet
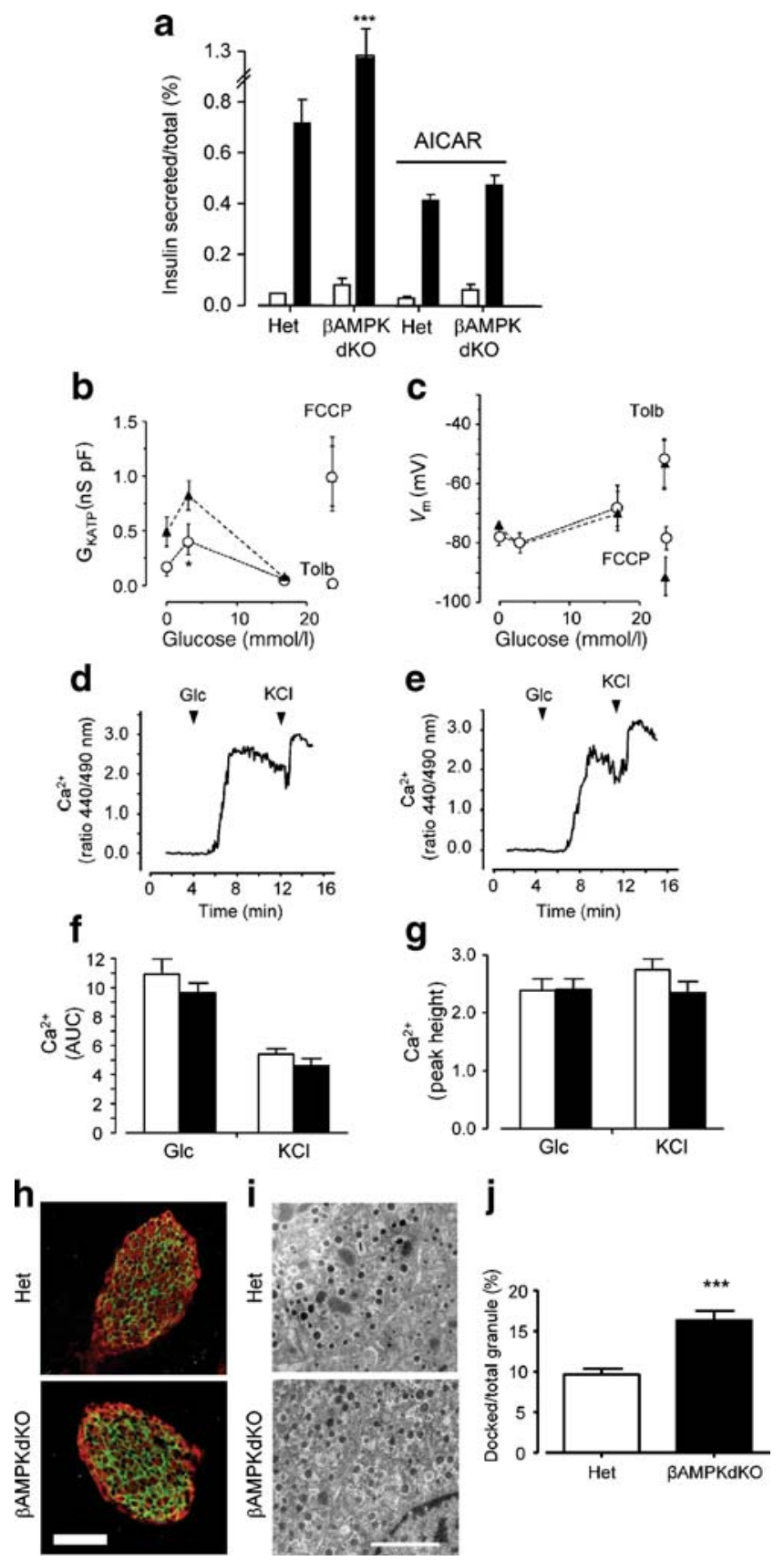


\section{a}

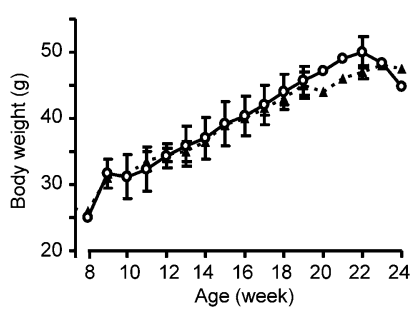

d

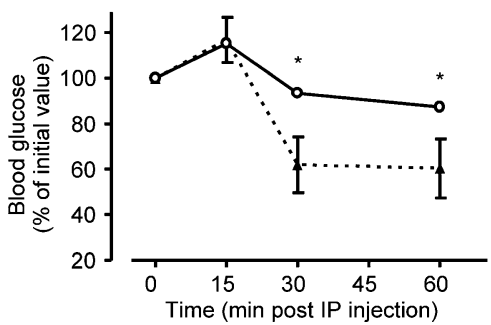

b

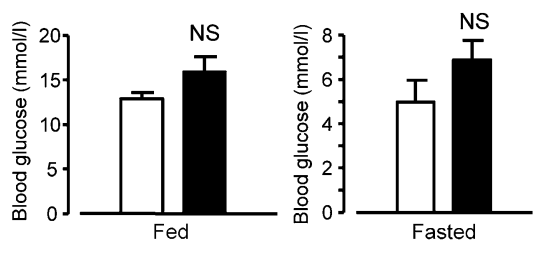

e

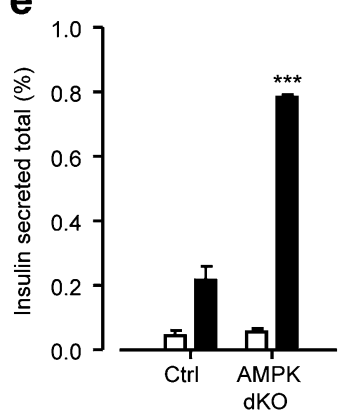

Fig. 7 AMPK deletion attenuates the deleterious effects of high-fat feeding on glucose tolerance. a Body weight changes in $\beta A M P K d K O$ (triangles) and heterozygous (circles) mice over 2 to 18 weeks on high-fat diet $(60 \%)$. b Blood glucose levels in $\beta$ AMPKdKO (black bars) and heterozygous (white bars) mice on high-fat diet for 6 weeks with free access to food or fasted for $15 \mathrm{~h}$. c Glucose tolerance after intraperitoneal (IP) glucose injection and (d) whole-body insulin sensitivity after IP insulin injection of $\beta$ AMPKdKO mice on high-fat diet for 6 weeks. Triangles, $\beta$ AMPKdKO; circles, heterozygous. e Glucose-stimulated insulin secretion of six size-matched islets from $\beta A M P K d K O$ and control (Ctrl) mice maintained on high-fat diet for 18 weeks. Islets were statically incubated at $3 \mathrm{mmol} / \mathrm{l}$ (white bars) and $16.7 \mathrm{mmol} / 1$ (black bars) glucose for $0.5 \mathrm{~h} . n=3$ mice per each genotype. Data are expressed as means $\pm \mathrm{SEM} ;{ }^{*} p<0.05, * * * p<0.001$
( $\sim 30 \%$ of initial glucose; Fig. $7 d$ ). Strikingly, the 3.5 -fold decrease in glucose-stimulated insulin secretion observed in islets from heterozygous mice maintained on high-fat diet compared with normal chow (from $\sim 0.7$ to $0.2 \%$ per $30 \mathrm{~min}$; Figs $6 \mathrm{a}$ and $7 \mathrm{e}$ ) was reduced in $\beta$ AMPKdKO mouse islets to $\sim 0.6$-fold (from $\sim 1.3$ to $0.8 \%$ per $30 \mathrm{~min}$.). Hence, $\beta$ AMPKdKO mice were still susceptible to the effects of high-fat diet, albeit to a lesser extent than controls.

Overexpression of constitutively active AMPK in beta cells causes glucose intolerance

The above results suggested that, at extrapancreatic sites of RIP2.Cre expression, notably in the mediobasal hypothalamus, AMPK activity is permissive of insulin secretion in vivo.

To determine whether increases in AMPK imposed selectively in beta cells affect insulin secretion in vivo, we generated transgenic mice in which the constitutively active enzyme (AMPK.CA) [6] was expressed under the control of the insulin promoter (Fig. 8a). Of two founder mouse lines generated (Fig. 8b), we examined in detail one line carrying two transgene copies. Overexpression of the mRNA was clearly evident in islets (Fig. 8c, d) and under the control of glucose ex vivo (as expected for expression under the insulin promoter; Fig. 8e), but barely $(<0.001 \%$ of the islet level) in the hypothalamus or other tissues (Fig. 8d, f), reflecting the more restricted expression of the RIP2 transgene to the beta cell in adult mice [44].

Islets from transgenic mice overexpressing AMPK.CA (AMPK.CA transgenic) displayed a significant increase in total $(\alpha 1+\alpha 2$ complex) AMPK activity at elevated $(16.7 \mathrm{mmol} / \mathrm{l})$, but not at low $(2.8 \mathrm{mmol} / \mathrm{l})$ glucose concentrations, where the endogenous enzyme was strongly activated (Fig. 8 g, h) [14]. Conversely, AMPK activity was reduced at low glucose concentrations in islets from AMPK.DN transgenic mice, generated in parallel with AMPK.CA mice (Fig. 8g, h). Assuming approximately equal endogenous AMPK levels in beta compared with islet non-beta cells (ESM Fig. 1) and an islet beta cell content of $60 \%$ [34], AMPK activity was increased by $36 \%$ and reduced by $50 \%$, in beta cells by overexpression of AMPK. CA or AMPK.DN respectively.

Maintained on normal chow, AMPK.CA and AMPK.DN transgenic mice displayed normal body weight increases (Fig. 9a, b). Whereas male AMPK.CA transgenic mice displayed abnormal glucose tolerance at 3 (Fig. 9c), but not 6 (Fig. 9e) months, no abnormalities were seen in AMPK. DN transgenic animals (Fig. 9d, f) or in female AMPK.CA mice (not shown). The abnormalities in AMPK.CA transgenic mice were not associated with any alterations in insulin sensitivity (Fig. 9g, h), but with decreased fasting 
a

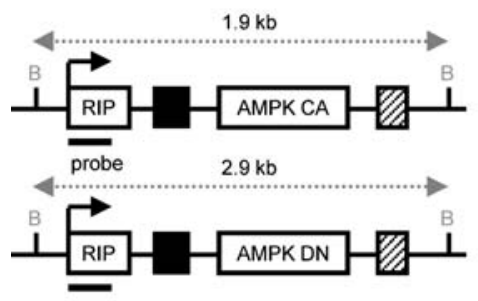

b

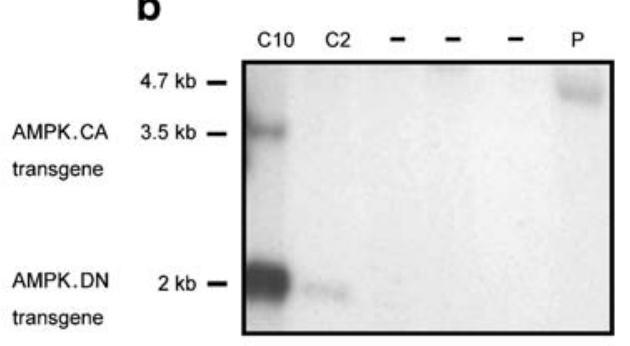

C

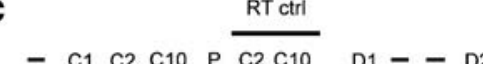

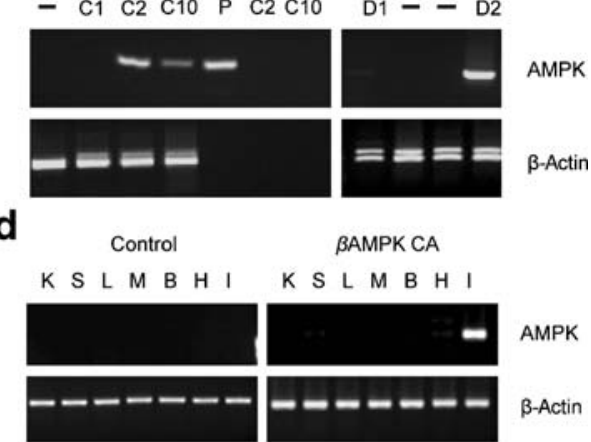

e

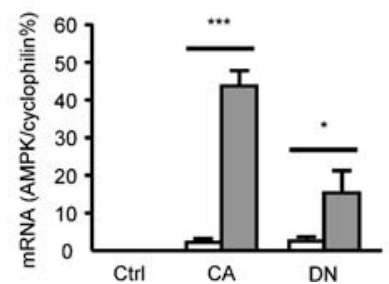

f

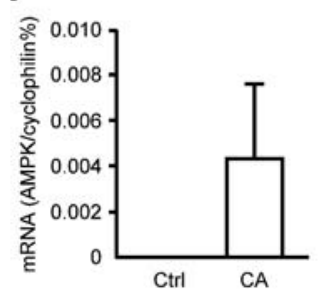

g

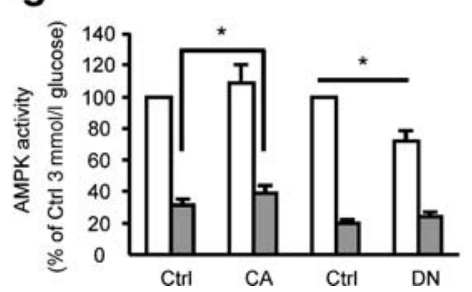

h

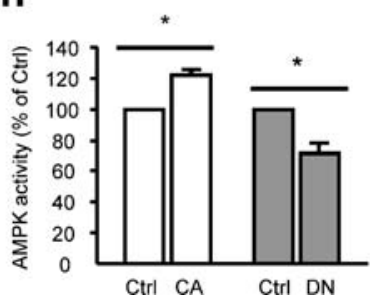

Fig. 8 Generation of $\beta$ AMPK.CA and $\beta$ AMPK.DN transgenic mice. a Schematic representation (not to scale) of RIP2-AMPK CA and DN constructs for generating the transgenic mice. Black square, c-myc sequence. Hatched square, poly A sequence. B, BssHII digestion site. b Southern blot analysis of tail DNA from offspring of $\beta$ AMPKCA founder mice. Expected fragment sizes of RIP2-AMPK CA constructs with linearisation of head-to-tail $(1.9 \mathrm{~kb})$ or of head-to-head $(3.5 \mathrm{~kb})$ in the mice genomic DNA after SpeI digestion and hybridisation with indicated probe situated in the RIP2 promoter are shown. P, two equivalent copies of RIP2-AMPK CA vectors $(4.7 \mathrm{~kb})$. c RT-PCR analysis of AMPK transgene expression in islets and (d) hypothalamus $(\mathrm{H})$, brain cortex (B), liver (L), spleen (S), kidney (K), muscle (M) and islet (I) from $\beta$ AMPK transgenic mice and their wild-type

and stimulated plasma insulin levels (Fig. 9i, j) and a 25\% decrease in beta cell area $(0.09 \pm 0.02 \%$ in wild-type vs $0.068 \pm 0.04 \%$ in transgenic littermates; data not shown). No significant changes in these variables were observed in AMPK.DN transgenic mice.

To determine whether the alterations in insulin secretion in AMPK.CA mice also result from defects at the level of the beta cell, we performed studies with isolated islets. Insulin release stimulated by $16.7 \mathrm{mmol} / \mathrm{l}$ glucose was decreased by $>60 \%$ (Fig. 9k), a similar change to that observed after maintenance of mice for 18 weeks on high-fat diet. Indeed, islets from AMPK.CA transgenic mice maintained on highfat diet displayed no further diminution in glucose-stimulated insulin secretion compared with wild-type littermates on the same diet (Fig. 9k). Conversely, glucose-stimulated insulin release was significantly enhanced in islets from AMPK.DN transgenic mice (Fig. 91), reminiscent of the effect of deleting AMPK $\alpha 1$ and $-\alpha 2$ subunits (Fig. 6a), although in this case the improved secretion was eliminated in islets from animals fed a high-fat diet. controls. C, AMPK.CA; D, AMPK.DN; dashed bar, wild-type; P, 5 ng AMPK.CA plasmid used for generating transgenic mice. e Quantification of real-time PCR analysis of AMPK transgene expression in islets and (f) hypothalamus from transgenic mice and their wild-type controls. Islets were incubated for $24 \mathrm{~h}$ at $3 \mathrm{mmol} / 1$ (white bars) or $16.7 \mathrm{mmol} / \mathrm{l}$ (grey bars) glucose before RNA extraction; $n=3$ mice per genotype. RNA was extracted from hypothalamic extracts immediately after isolation. $\mathbf{g}, \mathbf{h}$ Total AMPK activity in islets from transgenic mice and their wild-type littermate controls. Islets were incubated for $24 \mathrm{~h}$ at glucose concentrations as above (e, f) prior to extraction and assay (see ESM 1). Male mice aged from 12 to 14 weeks old were used; $n=3-5$. Results are from three or more independent experiments and are expressed as mean $\pm \mathrm{SEM} ;{ }^{*} p<0.05,{ }^{* * *} p<0.001$

\section{Discussion}

The principal aim of this study was to determine the physiological impact of complete and selective loss of both catalytic isoforms of AMPK from pancreatic beta cells. This is an important question, given the likely role of AMPK as a target for glucose-lowering drugs and uncertainties surrounding the role of AMPK in the beta cell $[5,6,15,18,21,45,46]$.

\section{Cell autonomous roles of AMPK within the beta cell}

Examined here in isolated islets and beta cells, total inactivation of AMPK led to a potentiation of glucoseinduced insulin secretion. We also noted an increase in ATP-sensitive $\mathrm{K}^{+}\left(\mathrm{K}_{\text {ATP }}\right)$ channel activity at low glucose concentrations (Fig. 4b, c), perhaps reflecting altered trafficking of channel subunits [47]. However, glucoseinduced $\mathrm{K}_{\text {АTP }}$ channel closure and increases in intracellular $\mathrm{Ca}^{2+}$ were unaltered, suggesting that the loss of an 

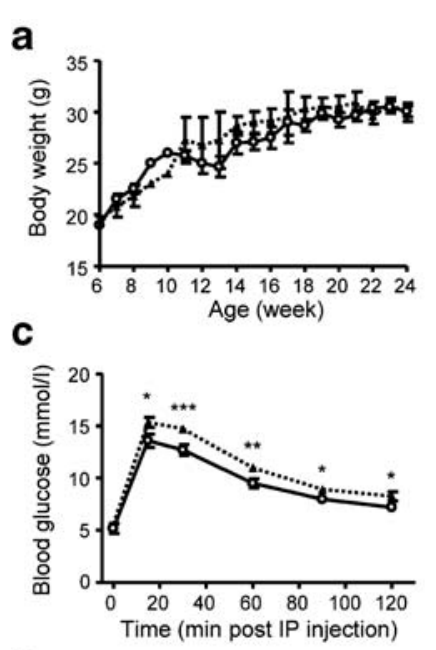

\section{e}
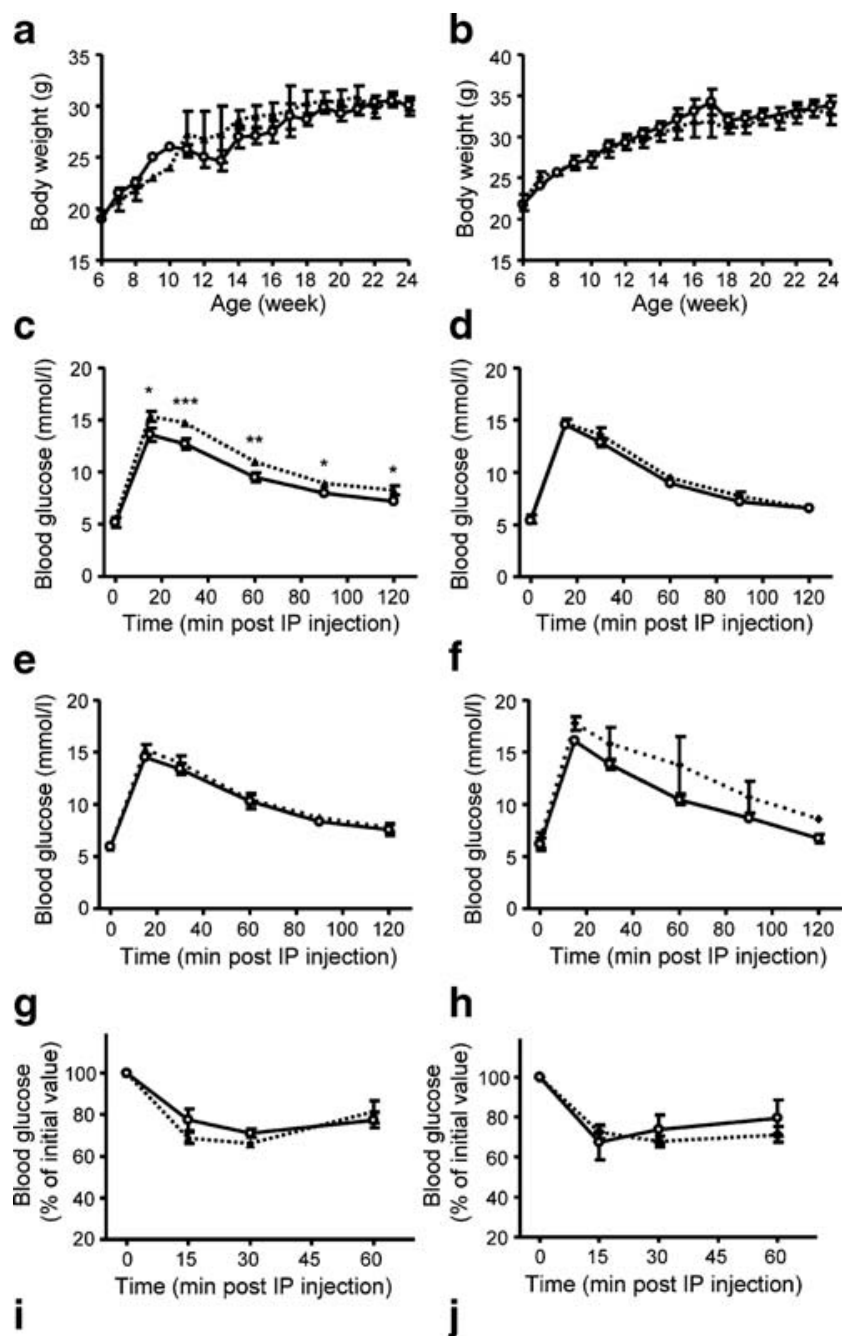

i

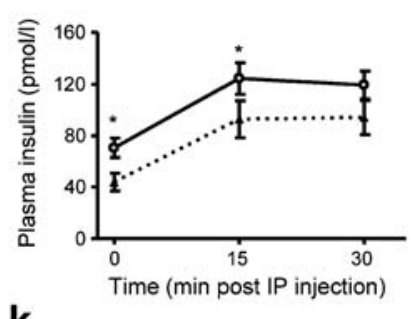

k
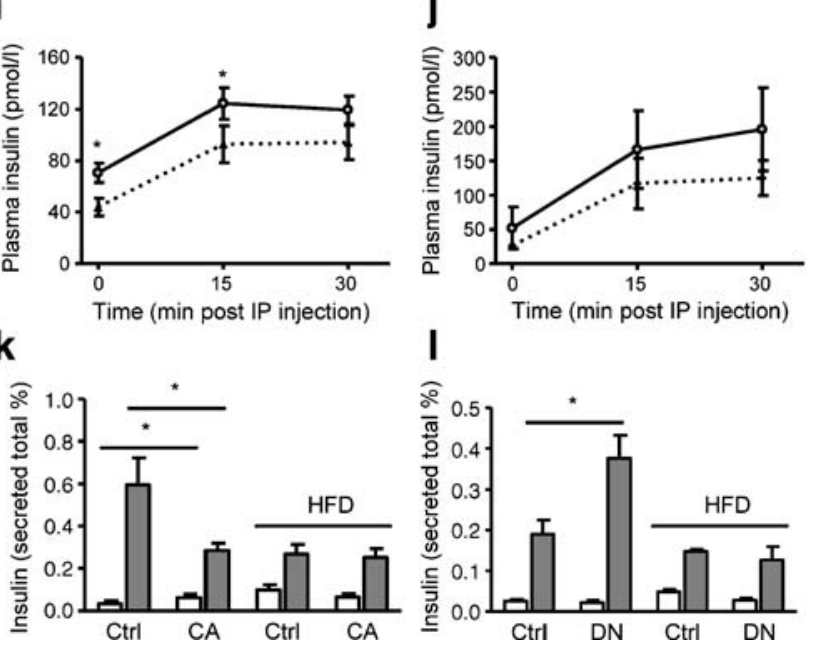

inhibitory effect of AMPK-mediated phosphorylation of kinesin light chains [16, 17] and increased granule translocation to the plasma membrane (Fig. 6i, j) may underlie the enhanced secretion. Conversely, selective activation of AMPK in beta cells in $\beta$ AMPK.CA transgenic mice decreased glucose-stimulated insulin secretion. These findings are consistent with previous results involving the
Fig. 9 BAMPK.CA transgenic mice display mild glucose intolerance and reduced insulin secretion. a Growth curves of body weights of AMPK.CA mice and (b) AMPK.DN mice aged 6 to 24 weeks old. c Glucose tolerance at 3 months in AMPK.CA and (d) AMPK.DN mice, and $(\mathbf{e}, \mathbf{f})$ at 6 months respectively. $\mathbf{g}$ Whole-body insulin sensitivity in AMPK.CA and (h) AMPK.DN mice, with $(\mathbf{i}, \mathbf{j})$ insulin response of respective 3-month-old mice assessed by intraperitoneal (IP) injection and measurements of glucose in tail vein at the indicated times (see the Methods). White symbols (a-j), $\beta$ AMPK.CA or $\beta$ AMPK.DN; black symbols, control. k Glucose-stimulated insulin secretion assessed in islets from $\beta$ AMPK.CA and (I) $\beta$ AMPK.DN transgenic mice and their wild-type littermate controls on normal chow or high-fat $(60 \%)$ diet (under the bar below HFD) for 18 weeks. Male mice aged 12-14 weeks were used; $n=8-13(\mathbf{a}-\mathbf{j}), n=3-5(\mathbf{k}, \mathbf{l})$. Data are expressed as means \pm SEM; $* p<0.05, * * p<0.01, * * * p<0.001$

overexpression in islets from of AMPK.CA animals in vitro [21], as well as with the effects of pharmacological activation of AMPK in clonal beta cells and isolated islets using AICAR or metformin [4, 6, 14, 48]. Furthermore, a diminished number of docked granules was observed in MIN6 cells overexpressing AMPK.CA [16].

We also show here that AMPK deletion leads to a decrease in cell volume, an effect strikingly different from that of deleting the upstream kinase, LKB1. Indeed, beta cells lacking LKB1 as a result of excision mediated either by RIP2.Cre (G. Sun, A. Tarasov, J. McGinty) or pancreas duodenum homeobox-1 promoter/Cre recombinaseoestrogen receptor (PDX-1-CreER) [38, 49] are larger than wild-type beta cells. LKB1 and AMPK appear therefore to engage substantially distinct downstream signalling pathways in beta cells, the former acting at least to a large extent via polarity-regulating kinase partitioning-defective $1 /$ microtubule affinity-regulating kinase 2 (PAR1B/MARK2) [38, 49].

In the present study, inactivation of AMPK in RIP2.Cre neurons exerted no apparent effect on body mass or food intake. However, $\alpha$ AMPKdKO mice displayed defective glucose homeostasis due to abnormalities in the capacity of a preserved beta cell mass to secrete insulin in response to hyperglycaemia. This deficiency was only partially compensated for by an increase in insulin sensitivity, probably due to increased insulin receptor levels or enhanced downstream signalling in target tissues [50]. Importantly, we used intraperitoneal injection of glucose, rather than oral administration to achieve increases in blood glucose concentration in the absence of a substantial release of incretins including glucagon-like peptide-1. In this way, we sought to compare the effects of an increase in circulating glucose in vivo with changes imposed on isolated islets. Nonetheless, we noted a dramatic decrease in insulin release in $\beta A M P K . d K O$ mice in vivo, which was not apparent in vitro.

We considered the possibility that decreases in beta cell and islet size contribute to this deficiency in insulin secretion in vivo. However, the absence of impaired insulin release from islets in vitro (in fact, the opposite was 
observed) makes it unlikely that these changes are responsible for the drastically impaired insulin release observed in vivo in $\beta$ AMPKdKO mice. It seems that the absence of the 'opposite' in vivo phenotype (i.e. improved glucose intolerance) in mice overexpressing activated AMPK under the same promoter (Fig. 9c, e, g, i) is most likely to reflect the predominant expression of the transgene in the pancreatic beta cell (rather than the hypothalamus) in adult mice. One possible explanation for these data is that a signal or signals emanating from RIP2.Cre neurons controls the activity of beta cells in vivo. Indeed, central administration of leptin has previously been shown to inhibit insulin secretion in vivo [51] and it is conceivable that this involves RIP2.Cre neurons and intracellular signalling pathways modulated by AMPK. Nevertheless, further and more definitive studies are needed to ascertain whether and by what means RIP.Cre neurons may influence insulin secretion.

A further interesting finding of the present studies is that mice lacking AMPK in the beta cell are somewhat less susceptible to the deleterious effects of high-fat diet on glucose metabolism and insulin secretion in vitro. These results are consistent with the previously demonstrated role of AMPK [18] in the actions of cytokines [19] on beta cell function and mass.

\section{Conclusions}

The results presented here suggest that activation of AMPK in hypothalamic neurons and in pancreatic beta cells play distinct roles in the control of insulin release in vivo. Our findings should inform the use and development of agents that act through AMPK to control glycaemia.

\begin{abstract}
Acknowledgements This work was supported by grants to G. A. Rutter from the Wellcome Trust (Programme Grant 081958/2/07/Z), The European Union (FP6 "Save Beta"), the Medical Research Council (G0401641) and National Institutes of Health (RO1 DK071962-01), as well as by a JDRFI Post-Doctoral Fellowship to A. I. Tarasov. We thank B. Kola (Queen Mary, University of London) for useful discussion, and P. Meda (University of Geneva) and B. Thorens (University of Lausanne) respectively for the kind provision of anti-ZO-1 and anti-GLUT2 antibodies. L. Lawrence is thanked for the preparation of pancreatic slices.
\end{abstract}

Duality of interest The authors declare that there is no duality of interest associated with this manuscript.

\section{References}

1. Shaw RJ, Lamia KA, Vasquez D et al (2005) The kinase LKB1 mediates glucose homeostasis in liver and therapeutic effects of metformin. Science 310:1642-1646
2. Towler MC, Hardie DG (2007) AMP-activated protein kinase in metabolic control and insulin signaling. Circ Res 100:328-341

3. Kurth-Kraczek EJ, Hirshman MF, Goodyear LJ, Winder WW (1999) 5' AMP-activated protein kinase activation causes GLUT4 translocation in skeletal muscle. Diabetes 48:1667-1671

4. Salt IP, Johnson G, Ashcroft SJ, Hardie DG (1998) AMPactivated protein kinase is activated by low glucose in cell lines derived from pancreatic beta cells, and may regulate insulin release. Biochem J 335:533-539

5. da Silva XG, Leclerc I, Salt IP et al (2000) Role of AMP-activated protein kinase in the regulation by glucose of islet beta-cell gene expression. Proc Natl Acad Sci U S A 97:4023-4028

6. da Silva XG, Leclerc I, Varadi A, Tsuboi T, Moule SK, Rutter GA (2003) Role for AMP-activated protein kinase in glucosestimulated insulin secretion and preproinsulin gene expression. Biochem J 371:761-774

7. Rutter GA, Leclerc I (2009) The AMP-regulated kinase family: Enigmatic targets for diabetes therapy. Mol Cell Endocrinol 297:41-49

8. Long YC, Zierath JR (2006) AMP-activated protein kinase signaling in metabolic regulation. J Clin Invest 116:1776-1783

9. Stapleton D, Woollatt E, Mitchelhill KI et al (1997) AMPactivated protein kinase isoenzyme family: subunit structure and chromosomal location. FEBS Lett 409:452-456

10. Hardie DG, Carling D (1997) The AMP-activated protein kinase-fuel gauge of the mammalian cell? Eur J Biochem 246: 259-273

11. Viollet B, Andreelli F, Jorgensen SB et al (2003) Physiological role of AMP-activated protein kinase (AMPK): insights from knockout mouse models. Biochem Soc Trans 31:216-219

12. Jorgensen SB, Viollet B, Andreelli F et al (2004) Knockout of the $\alpha 2$ but not $\alpha 1$ 5'-AMP-activated protein kinase isoform abolishes 5 -aminoimidazole-4-carboxamide-1- $\beta$-4-ribofuranoside but not contraction-induced glucose uptake in skeletal muscle. J Biol Chem 279:1070-1079

13. Viollet B, Andreelli F, Jorgensen SB et al (2003) The AMPactivated protein kinase alpha2 catalytic subunit controls wholebody insulin sensitivity. J Clin Invest 111:91-98

14. Leclerc I, Woltersdorf WW, da Silva XG et al (2004) Metformin, but not leptin, regulates AMP-activated protein kinase in pancreatic islets: impact on glucose-stimulated insulin secretion. Am J Physiol Endocrinol Metab 286:E1023-E1031

15. Richards SK, Parton LE, Leclerc I, Rutter GA, Smith RM (2006) Over-expression of AMP-activated protein kinase impairs pancreatic beta-cell function in vivo. J Endocrinol 187:225-235

16. Tsuboi T, da Silva XG, Leclerc I, Rutter GA (2003) 5' AMPactivated protein kinase controls insulin-containing secretory vesicle dynamics. J Biol Chem 278:52042-52051

17. McDonald A, Fogarty S, Leclerc I, Hill E, Hardie DG, Rutter GA (2009) Control of insulin granule dynamics by AMPK-dependent KLC1 phosphorylation. Islets 1:1-11

18. Kefas BA, Heimberg H, Vaulont $\mathrm{S}$ et al (2003) AICAriboside induces apoptosis of pancreatic beta cells through stimulation of AMP-activated protein kinase. Diabetologia 46: $250-254$

19. Riboulet-Chavey A, Diraison F, Siew LK, Wong FS, Rutter GA (2008) Inhibition of AMP-activated protein kinase protects pancreatic $\beta$-cells from cytokine-mediated apoptosis and $\mathrm{CD} 8^{+}$ T cell-induced cytotoxicity. Diabetes 57:415-423

20. Jones RG, Plas DR, Kubek S et al (2005) AMP-activated protein kinase induces a p53-dependent metabolic checkpoint. Mol Cell 18:283-293

21. Gleason CE, Lu D, Witters LA, Newgard CB, Birnbaum MJ (2007) The role of AMPK and mTOR in nutrient sensing in pancreatic beta-cells. J Biol Chem 282:10341-10351 
22. Minokoshi Y, Alquier T, Furukawa N et al (2004) AMP-kinase regulates food intake by responding to hormonal and nutrient signals in the hypothalamus. Nature 428:569-574

23. McCrimmon RJ, Fan X, Cheng $\mathrm{H}$ et al (2006) Activation of AMP-activated protein kinase within the ventromedial hypothalamus amplifies counterregulatory hormone responses in rats with defective counterregulation. Diabetes 55:1755-1760

24. McCrimmon RJ, Shaw M, Fan X et al (2008) Key role for AMPactivated protein kinase in the ventromedial hypothalamus in regulating counterregulatory hormone responses to acute hypoglycemia. Diabetes 57:444-450

25. Claret M, Smith MA, Batterham RL et al (2007) AMPK is essential for energy homeostasis regulation and glucose sensing by POMC and AgRP neurons. J Clin Invest 117:2325-2336

26. Mountjoy PD, Bailey SJ, Rutter GA (2007) Inhibition by glucose or leptin of neuropeptide Y-expressing hypothalamic neurons requires changes in AMP-activated protein kinase activity. Diabetologia 50:168-177

27. Canabal DD, Song Z, Potian JG, Beuve A, McArdle JJ, Routh VH (2006) Glucose, insulin and leptin signaling pathways modulate nitric oxide (NO) synthesis in glucose-inhibited (GI) neurons in the ventromedial hypothalamus (VMH). Am J Physiol Regul Integr Comp Physiol 292:R1418-R1428

28. Wyatt CN, Mustard KJ, Pearson SA et al (2007) AMP-activated protein kinase mediates carotid body excitation by hypoxia. J Biol Chem 282:8092-8098

29. Choudhury AI, Heffron H, Smith MA et al (2005) The role of insulin receptor substrate 2 in hypothalamic and beta cell function. J Clin Invest 115:940-950

30. Lee JY, Ristow M, Lin X, White MF, Magnuson MA, Hennighausen L (2006) RIP-Cre revisited, evidence for impairments of pancreatic beta-cell function. J Biol Chem 281: 2649-2653

31. Pomplun D, Florian S, Schulz T, Pfeiffer AF, Ristow M (2007) Alterations of pancreatic beta-cell mass and islet number due to Ins2-controlled expression of Cre recombinase: RIP-Cre revisited; part 2. Horm Metab Res 39:336-340

32. Reimann F, Habib AM, Tolhurst G, Parker HE, Rogers GJ, Gribble FM (2008) Glucose-sensing in L-cells: a primary cell study. Cell Metabolism 8:532-539

33. Nicolson TJ, Bellomo EA, Wijesekara N et al (2009) Insulin storage and glucose homeostasis in mice null for the granule zinc transporter ZnT8 and studies of the type 2 diabetes-associated variants. Diabetes 58:2070-2083

34. Rahier J, Goebbels RM, Henquin JC (1983) Cellular composition of the human diabetic pancreas. Diabetologia 24:366-371

35. Cerasi E, Effendic S, Luft R (1969) Role of adrenergic receptors in glucose-induced insulin secretion in man. Lancet 2:301-302

36. Alanentalo T, Asayesh A, Morrison H et al (2007) Tomographic molecular imaging and $3 \mathrm{D}$ quantification within adult mouse organs. Nat Methods 4:31-33
37. Williams T, Brenman JE (2008) LKB1 and AMPK in cell polarity and division. Trends Cell Biol 18:193-198

38. Fu A, Ng AC, Depatie C et al (2009) Loss of Lkb1 in adult beta cells increases beta cell mass and enhances glucose tolerance in mice. Cell Metab 10:285-295

39. Granot Z, Swisa A, Magenheim J et al (2009) LKB1 regulates pancreatic beta cell size, polarity, and function. Cell Metab 10:296-308

40. Shaw RJ (2009) LKB1 and AMP-activated protein kinase control of mTOR signalling and growth. Acta Physiol (Oxf) 196: $65-80$

41. Fingar DC, Salama S, Tsou C, Harlow E, Blenis J (2002) Mammalian cell size is controlled by mTOR and its downstream targets S6K1 and 4EBP1/eIF4E. Genes Dev 16:1472-1487

42. Thorens B, Sarkar HK, Kaback HR, Lodish HF (1988) Cloning and functional expression in bacteria of a novel glucose transporter present in liver intestine kidney and B-pancreatic islet cells. Cell 55:281-290

43. Ahren B, Simonsson E, Scheurink AJ, Mulder H, Myrsen U, Sundler F (1997) Dissociated insulinotropic sensitivity to glucose and carbachol in high-fat diet-induced insulin resistance in C57BL/6J mice. Metabolism 46:97-106

44. Gannon M, Shiota C, Postic C, Wright CVE, Magnuson M (2000) Analysis of the Cre-mediated recombination driven by rat insulin promoter in embryonic and adult mouse pancreas. Genesis 26: $139-142$

45. Kefas BA, Cai Y, Ling Z et al (2003) AMP-activated protein kinase can induce apoptosis of insulin-producing MIN6 cells through stimulation of c-Jun-N-terminal kinase. J Mol Endocrinol 30:151-161

46. Kefas BA, Cai Y, Kerckhofs K et al (2004) Metformin-induced stimulation of AMP-activated protein kinase in b-cells impairs their glucose-responsiveness and can lead to apoptosis. Biochem Pharmacol 68:409-416

47. Lim A, Park SH, Sohn JW et al (2009) Glucose deprivation regulates KATP channel trafficking via AMP-activated protein kinase (AMPK) in pancreatic $\beta$-cells. Diabetes 58:2813-2819

48. Targonsky ED, Dai F, Koshkin V et al (2006) alpha-lipoic acid regulates AMP-activated protein kinase and inhibits insulin secretion from beta cells. Diabetologia 49:1587-1598

49. Hezel AF, Gurumurthy S, Granot Z et al (2008) Pancreatic LKB1 deletion leads to acinar polarity defects and cystic neoplasms. Mol Cell Biol 28:2414-2425

50. Buren J, Liu HX, Lauritz J, Eriksson JW (2003) High glucose and insulin in combination cause insulin receptor substrate-1 and -2 depletion and protein kinase $\mathrm{B}$ desensitisation in primary cultured rat adipocytes: possible implications for insulin resistance in type 2 diabetes. Eur J Endocrinol 148:157-167

51. Kalra SP (2008) Disruption in the leptin-NPY link underlies the pandemic of diabetes and metabolic syndrome: new therapeutic approaches. Nutrition 24:820-826 